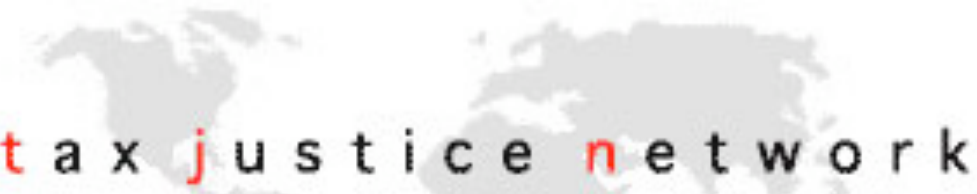

IDENTIFYING TAX HAVENS AND OFFSHORE FINANCE CENTRES

Various attempts have been made to identify and list tax havens and offshore finance centres (OFCs). This Briefing Paper aims to compare these lists and clarify the criteria used in preparing them.

\section{Features of Havens}

Tax havens and OFCs are closely related, although not every jurisdiction ${ }^{1}$ would fall into both categories. They are also similar in that, while almost any jurisdiction can have some tax haven or OFC features, a smaller number are usually identified as 'pure' tax havens or OFCs.

The central feature of a haven is that its laws and other measures can be used to evade or avoid the tax laws or regulations of other jurisdictions. Minimisation of tax liability is an important element. This generally depends on (i) use of paper or 'shell' companies, trusts and other legal entities, and (ii) routing and managing financial flows. Hence, tax and financial management are closely linked.

Pure tax havens or OFCs generally have laws specifically designed for such purposes, aiming to attract financial and corporate services business, and such business is a major part of their economy.

The main element of their attractiveness is secrecy. This includes

(i) strong bank secrecy: information can not (or not easily) be obtained from banks and other financial institutions for official purposes such as tax collection (including other countries' taxes);

(ii) secrecy of legal entities: information is not available or obtainable about companies, corporations, trusts, foundations, or other legal entities, such as the beneficial owners (e.g. shareholders of a company, or beneficiaries of a trust), details of persons with power to determine the use of assets, or financial accounts.

In addition, they generally offer specific advantages, especially a zero or low tax rate, to non-residents or foreign-owned legal entities.

\footnotetext{
${ }^{1}$ The term jurisdiction is used here, as generally in this context, to describe any territory with its own legal system, regardless of whether it is an independent or sovereign state; it may be a component of a federal or confederal state (e.g. Dubai), a dependent, associated or overseas territory (e.g. Cayman Islands, Isle of Man); or an internal zone to which a special legal regime has been applied (e.g. Labuan).
} 


\section{OECD list of tax havens}

The main listings of tax havens have been developed by the Organisation for Economic Cooperation and Development (OECD), as part of the project against 'harmful tax practices' of its Committee on Fiscal Affairs (CFA). The OECD 1998 report which launched this project defined a tax haven as a jurisdiction which has:

(a) no or only nominal taxes (generally or in special circumstances) and offers itself, or is perceived to offer itself, as a place to be used by nonresidents to escape tax in their country of residence;

(b) laws or administrative practices which prevent the effective exchange of relevant information with other governments on taxpayers benefiting from the low or no tax jurisdiction;

(c) lack of transparency, and

(d) the absence of a requirement that the activity be substantial, since it would suggest that a jurisdiction may be attempting to attract investment or transactions that are purely tax driven (transactions may be booked there without the requirement of adding value so that there is little real activity, i.e. these jurisdictions are essentially "booking centres")." (OECD 1998, 2223)

However, the fourth criterion of 'no substantial activities' was rejected by the new US administration as announced by Treasury Secretary O'Neill in July 2001, and it was formally withdrawn in the OECD's 2002 Progress report (OECD 2001, 10).

The OECD-CFA initially identified 47 possible tax havens, but 6 of these were found not to qualify. In 2000, therefore the OECD identified 41 tax havens, of which 6 had made commitments to cooperate. These 41 are indicated in the first column of the Table. The OECD list entails judgments about 'reputation' and results in a list made up essentially of small jurisdictions. Not surprisingly they complained, and pointed to the important role of financial centres such as Luxembourg and Switzerland (which had refused to support the OECD initiative), as well as others such as the UK (City of London) and Ireland, and other non-OECD jurisdictions such as Singapore and Dubai. This led to the establishment of the OECD Global Forum on Taxation, which has worked on establishing global standards of fiscal transparency for a 'level playing field'. (Sharman, 2006).

The OECD project on harmful tax practices has aimed at obtaining commitments from jurisdictions identified as tax havens to improving transparency and establishing effective exchange of information. By 2007 it reported that 33 jurisdictions had made such commitments, while 5 remained 'uncooperative' (Andorra, Liechtenstein, Monaco, Liberia, ${ }^{2}$ and the Marshall Islands). The OECD also determined that 3 jurisdictions (Barbados, Maldives and Tonga) should no longer be considered tax havens, leaving 38 of the 41 identified in 2000 which are still considered tax havens by the OECD.

\footnotetext{
${ }^{2}$ The new government in Liberia is likely to make a commitment, and so may be listed as cooperative soon.
} 


\section{OECD list of harmful preferential tax regimes}

The OECD 1998 report also proposed the identification of 'harmful preferential tax regimes' of OECD member countries. The report identifies four features of harmful preferential tax regimes:

“(a) No or low effective tax rate

(b) "Ring fencing" of regimes (preferential tax regimes are partly or fully insulated from the domestic markets to protect own economy)

(c) Lack of transparency

(d) Lack of effective exchange of information" (OECD 1998, 26-27)

The report also distinguishes nine additional factors that can assist to identify harmful preferential tax regimes (OECD 1998, 30-35). It is notable that one additional factor, namely the regime encourages purely tax-driven operations or arrangements, corresponds to the fourth criterion for a 'pure' tax haven. In addition, a number of these additional factors, such as an artificial definition of the tax base, foreign source income exempt from residence country tax, and negotiable tax rate or tax base, result in a low effective tax rate. This is similar to the first criterion for a 'pure' tax haven (no or low nominal tax rate). An additional factor is that the regimes promote themselves as tax minimisation vehicles, meaning that they aim to support their reputation of being a 'tax haven'.

This produced a list of 47 potentially harmful regimes in 20 OECD countries (OECD $2000,12-14)$. The outcome of the reviews of these regimes was reported in 2004 , which concluded that regimes had either been abolished in the mean time or were not harmful OECD 2004, 7-9) . These did not include holding company regimes, which were still being evaluated. A follow-up published in 2006 also reviewed holding company regimes, and concluded that all were either not harmful or had been withdrawn, with the exception of Luxembourg's (OECD 2006).

In parallel, the EU conducted a similar review of harmful tax regimes in member states and their dependencies, applying criteria identified in the EU Code of Conduct on Business Taxation (EU, 1998). This resulted in a report made available in 1999 (the Primarolo Report) containing a detailed evaluation of measures identified as potentially harmful, and measures in 13 member states were positively so identified. ${ }^{3}$ The EU states involved were the same as those in the OECD list (including Austria, in relation to its holding company regime). ${ }^{4}$

The countries with harmful preferential tax regimes are indicated in the first column of the table as white squares.

\footnotetext{
${ }^{3}$ The EU's Code of Conduct group is still continuing its work, but since this is being done in secret, it is not known whether the changes made by states are considered to have ended the various preferential régimes. The OECD is also continuing to monitor newly introduced preferential regimes of its member states (OECD 2006, para. 16), and its reviews of availability of information for tax purposes also include OECD members.

${ }^{4}$ The OECD cleared Austria after amendment of its holding company regime (OECD, 2004, 10)
} 


\section{List of OFCs based on regulatory criteria}

Similar efforts have been made to identify jurisdictions which are offshore financial centres (OFCs). A list was produced in a report produced by the Financial Stability Forum (FSF) in 2000. The FSF considered the criteria below. These are based on regulatory characteristics of a jurisdiction and largely similar to the OECD criteria for tax havens and harmful preferential tax regimes.

"Offshore financial centres (OFCs) are not easily defined, but they can be characterised as jurisdictions that attract a high level of non-resident activity. Traditionally, the term has implied some or all of the following (but not all OFCs operate this way):

- Low or no taxes on business or investment income;

- No withholding taxes;

- Light and flexible incorporation and licensing regimes;

- Light and flexible supervisory regimes;

- Flexible use of trusts and other special corporate vehicles;

- No need for financial institutions and/or corporate structures to have a physical presence;

- An inappropriately high level of client confidentiality based on impenetrable secrecy laws;

- Unavailability of similar incentives to residents.” (FSF 2000, 9).

The FSF identified a Compendium of Standards relating to, amongst other matters, regulation of financial institutions and markets. A programme for monitoring of compliance by their members states with these standards was established by the International Monetary Fund (IMF) and World Bank (WB) in 1999, and this was extended in 2000 to cover jurisdictions identified as OFCs. The IMF-WB programme used a list of OFCs based on the FSF list, plus four additional jurisdictions (Dominica, Grenada, Montserrat, Palau). The IMF-WB list of OFCs is in the third column of the Table.

\section{List of OFCs based on economic statistics}

In 2007 the IMF published a Working Paper by Ahmed Zoromé aimed at providing an objective and quantifiable method of identifying OFCs. Surveying the various definitions put forward by scholars and practitioners, the author concludes:

"Three distinctive and recurrent characteristics of OFCs have emerged from these definitions: (i) the primary orientation of business toward nonresidents; (ii) the favorable regulatory environment (low supervisory requirements and minimal information disclosure) and; (iii) the low-or zerotaxation schemes." (Zoromé 2007, 4).

These characteristics are again similar to the OECD characteristics of tax havens. Zoromé argues that the key or intrinsic feature of OFCs is:

“(...) the provision of financial services to nonresidents, namely, exports of financial services. Although one could argue that any given economy, to some extent, provides financial services, the peculiarity of OFCs is that they have specialized in the supply of financial services on a scale far exceeding 
the needs and the size of their economies. The following definition attempts to capture that feature so characteristic of OFCs.

An OFC is a country or jurisdiction that provides financial services to nonresidents on a scale that is incommensurate with the size and the financing of its domestic economy." (Zoromé 2007, 7; bold and italics in the original, footnotes omitted).

The paper goes on to apply this definition in the development of a proposed methodology for identifying OFCs based on economic statistics rather than regulatory characteristics, which are considered more subjective. A major difficulty is the lack of, and limitations on, the available data. The lack of detailed data in the balance of payments statistics reported by many countries leads the Zoromé paper to propose that when current account data on payments for net exports of financial services are unavailable, data on portfolio investment assets in the capital accounts should be used as a proxy.

The second important issue is the proposed methodology for identifying the countries whose financial services provision to nonresidents is 'incommensurate' with its domestic economy. The Zoromé paper takes the ratio of net exports of financial services to GDP (calculated using the portfolio assets proxy if necessary). However, in order to identify which countries have a ratio significantly differing from the mean, countries are banded into High, and Middle/Low-Income countries. Although a number of jurisdictions generally recognised as OFCs are High Income (e.g. The Bahamas, Cayman Islands, Channel Islands, Isle of Man, Netherlands Antilles), the banding has the effect of bringing into the definition some which under a single ratio would not (Barbados and Uruguay). Another consequence of using net financial services exports as an indicator is that specific financial centres within larger countries, or countries with harmful preferential tax regimes, may not be classified as OFCs because the weight of the rest of the economy in the indicator is much larger.

The issue of what level of deviation from the mean should provide the cut-off is also significant. Notably, applying a threshold of one standard deviation above the mean, the UK is identified as an OFC by the study, which has attracted inevitable comment. The UK would be excluded if a higher threshold of two standard deviations were applied.

The 104 jurisdictions in its sample did not include several of those in the IMF-WB list that are generally recognised as tax havens or OFCs, such as Andorra, the British Virgin Islands, Liberia, Liechtenstein, Maldives, Marshall Islands, Monaco, Montserrat, and the US Virgin Islands. This may be remedied if more countries begin to collect and supply relevant data, which is being attempted through the IMF's Information Framework Initiative.

Finally, some tax havens specialise in provision of corporate and trust formation and management rather than financial services. Since the IMF's main concern is financial stability, a list based on financial services provision may be suitable for its purposes, but it might overlook jurisdictions which are important facilitators of money laundering and tax evasion or avoidance. The management of shell companies may be paid for by shell companies themselves, for example, which qualifies as a domestic sale of financial services instead of an export. It can be concluded that Zoromé's paper largely captures offshore management of personal wealth, but largely overlooks offshore management of corporate structures, which 
is an integral part of the OFC and tax haven criteria listed above. Including these activities in a statistical framework would require additional indicators of a different nature.

There is considerable overlap between the lists of tax havens and of OFCs. However, some tax havens are not identified as OFCs, especially if the criteria applied are based only on financial services provision. For example, Liberia has a shipping and corporate registry which is actually operated by a private company located in the USA, which facilitates both 'flagging out' of ships and tax evasion, so it is listed by the OECD as a tax haven; but it does not offer financial services. On the other hand, OFCs do generally offer tax advantages. Nevertheless, not all the OFCs are included in the OECD's tax havens list, essentially because the OECD only listed small tax haven jurisdictions, although harmful preferential tax regimes in large OECD countries were examined too. The OECD has since been pushed to address the role both of OECD countries and of jurisdictions such as Singapore and Dubai by the pressure for a level playing field.

\section{Tax Justice Network list of tax havens}

Tax Justice Network's (TJN) approach aims to be comprehensive, so the list produced in 2007 was a lengthy one. It included OECD countries that offer some tax haven facilities or offshore financial services, even if they do not account for a major part of the economy. This means that the all jurisdictions in the OECD tax haven list are included. These can be referred to as 'pure' tax havens: the standard offshore island states which facilitate tax avoidance through low tax rates and secrecy (SOMO, 2006).

In addition, TJN also considers OECD member countries with harmful preferential tax regimes as tax havens. According to TJN, countries with a broader economic base have a greater responsibility to end any provisions in their laws which facilitate avoidance of the laws of others, and it should not be only the small jurisdictions that are targeted.

Furthermore, TJN extended its tax haven list by performing a reputation test. Various members of the network have proposed countries that they view to be a tax haven. The composers of the list then conducted a reputation test by reviewing tax planning websites and reviewing documentation of tax legislation in the jurisdiction. 


\section{Conclusion}

There does not exist a single, unambiguous definition of a tax haven or an OFC. Some regulatory criteria, such as secrecy and low or zero taxes, appear in one form or another in each definition. However, the different lists of tax havens or offshore financial centres are based on different methods and indicators to identify such jurisdictions.

Some lists include only specific types of tax havens or OFCs. The recent Zoromé study, for example, only considers financial services and focuses on the provision of financial services. It does not capture havens which mainly provide secrecy through shell companies or trusts. Other lists, notably the list published by TJN in 2007, are more comprehensive and include diverse types of tax haven jurisdictions. Each approach may have its own merits and serve specific goals.

In a future paper of TJN, it might be useful to further distinguish different types of services provided by tax havens. On the one hand, this has a theoretical value, because this would provide more clarity on how firms or individuals could avoid taxation using certain tax haven facilities. On the other hand, it will also have practical value, because this creates the possibility to more specifically target tax havens offering certain services to address the negative consequences of the services involved Finally, such an approach might be more accurate and more informative than a general reputation test. 


\begin{tabular}{|c|c|c|c|c|}
\hline Jurisdiction & $\begin{array}{c}\text { COUNT } \\
\text { RY } \\
\text { CODE }\end{array}$ & OECD & FSF-IMF 2000 & TJN 2005 \\
\hline 1. Andorra & $\mathrm{AD}$ & 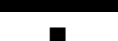 & n & - \\
\hline 2. Anguilla & $\mathrm{Al}$ & 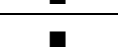 & 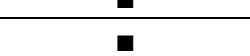 & 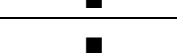 \\
\hline 3. Antigua \& Barbuda & AG & - & - & $\square$ \\
\hline 4. Aruba & AW & - & - & - \\
\hline 5. Australia & $\mathrm{AU}$ & $\square$ & & \\
\hline 6. Austria & AT & $\square$ & & \\
\hline 7. Bahamas & BS & - & - & - \\
\hline 8. Bahrain & $\mathrm{BH}$ & - & - & - \\
\hline 9. Barbados & BB & 口י & - & - \\
\hline 10. Belgium & $\mathrm{BE}$ & $\square$ & & - \\
\hline 11. Belize & BZ & - & ! & - \\
\hline 12. Bermuda & BM & - & - & - \\
\hline 13. British Virgin Islands & VG & - & - & - \\
\hline 14. Canada & CA & $\square$ & & \\
\hline 15. Cayman Islands & KY & - & - & - \\
\hline 16. Cook Islands & CK & - & - & - \\
\hline 17. Costa Rica & CR & & - & - \\
\hline 18. Cyprus & CY & - & - & - \\
\hline 19. Dominica & DM & - & - & - \\
\hline 20. Dubai & $\mathrm{AE}$ & & & - \\
\hline 21. Finland (Åland) & FI & $\square$ & & \\
\hline 22. France & FR & $\square$ & & \\
\hline 23. Germany (Frankfurt) & $\mathrm{DE}$ & $\square$ & & - \\
\hline 24. Gibraltar & GI & - & - & - \\
\hline 25. Greece & GR & $\square$ & & \\
\hline 26. Grenada & GD & - & - & - \\
\hline 27. Guernsey, Sark \& Alderney & GG & $\square$ & - & - \\
\hline 28. Hong Kong & HK & & - & - \\
\hline 29. Hungary & $\mathrm{HU}$ & $\square$ & & - \\
\hline 30. Iceland & IS & $\square$ & & - \\
\hline 31. Ireland & IE & $\square$ & - & - \\
\hline 32. Isle of Man & IM & - & - & - \\
\hline 33. Israel (Tel Aviv) & IL & & & - \\
\hline $\begin{array}{l}\text { 34. Italy (Campione d'Italia \& } \\
\text { Trieste) }\end{array}$ & IT & $\square$ & & - \\
\hline 35. Jersey & JE & $\square$ & - & - \\
\hline 36. Korea & KR & $\square$ & & \\
\hline 37. Latvia & LV & & & \\
\hline 38. Lebanon & LB & & - & - \\
\hline 39. Liberia & LR & - & & - \\
\hline 40. Liechtenstein & LI & - & - & - \\
\hline 41. Luxembourg & LU & $\square$ & - & - \\
\hline 42. Macao & MO & & - & - \\
\hline 43. Malaysia (Labuan) & MY & & - & - \\
\hline 44. Maldives & MV & 口י & & - \\
\hline 45. Malta & MT & - & - & - \\
\hline 46. Marshall Islands & $\mathrm{MH}$ & I & I & . \\
\hline
\end{tabular}




\section{Table 1 (continued): The world's tax havens and offshore financial centres}

Jurisdiction COUNT

\section{Mauritius}

48. Monaco

49. Montserrat

50. Nauru

51. Netherlands

52. Netherlands Antilles

53. Niue

54. Northern Mariana Islands

55. Palau

56. Panama

57. Portugal (Madeira)

58. Russia (Ingushetia)

59. Saint Kitts \& Nevis

60. Saint Lucia

61. Saint Vincent \& the Grenadines

\section{Samoa}

63. San Marino

64. São Tomé e Principe

65. Seychelles

66. Singapore

67. Somalia

68. South Africa

69. Spain (Melilla)

70. Sweden

71. Switzerland

72. Taiwan (Taipei)

73. Tonga

74. Turkey (Istanbul)

75. Turkish Rep. of Northern Cyprus

76. Turks \& Caicos Islands

77. United Kingdom (City of London)

78. Uruguay

79. US Virgin Islands

80. USA (New York)

81. Vanuatu

\section{RY \\ CODE}

FSF-IMF 2000

TJN 2005

\begin{tabular}{|c|c|c|c|}
\hline MU & घ & - & - \\
\hline$M C$ & $\square$ & $\square$ & I \\
\hline MS & घ & E & I \\
\hline NR & $\square$ & घ & I \\
\hline $\mathrm{NL}$ & $\square$ & & $\square$ \\
\hline AN & I & घ & I \\
\hline $\mathrm{NU}$ & $\square$ & $\pi$ & $\pi$ \\
\hline \multirow[t]{2}{*}{ MP } & & & I \\
\hline & & घ & \\
\hline PA & घ & घ & E \\
\hline PT & $\square$ & & I \\
\hline RU & & & I \\
\hline KN & घ & घ & I \\
\hline LC & घ & घ & $\square$ \\
\hline VC & " & प & - \\
\hline WS & I & [ & - \\
\hline SM & . & & \\
\hline ST & & & ח \\
\hline SC & - & " & - \\
\hline SG & & घ & I \\
\hline SO & 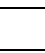 & & I \\
\hline $\mathrm{ZA}$ & & & I \\
\hline ES & $\square$ & & $\square$ \\
\hline $\mathrm{SE}$ & $\square$ & & \\
\hline $\mathrm{CH}$ & $\square$ & a & I \\
\hline TW & & & - \\
\hline TO & E & & E \\
\hline \multirow[t]{2}{*}{ TR } & $\square$ & & \\
\hline & & & - \\
\hline TC & I & घ & I \\
\hline UK & & & I \\
\hline UY & & & I \\
\hline $\mathrm{VI}$ & घ & & $\pi$ \\
\hline US & 口 & & I \\
\hline VU & $\pi$ & घ & I \\
\hline
\end{tabular}

- $\quad$ Tax Haven OECD, TJN 2007 / Offshore Financial Centre FSF/IMF 2000

OECD member country with potentially harmful preferential tax regime as distinguished by OECD 2000

- No longer regarded a tax haven according to the OECD 2006 


Table 2: Total number of tax havens and offshore financial centres
\begin{tabular}{|l|l|}
\hline List & Total number of tax havens / Offshore Financial Centres \\
\hline OECD 2000 / EU & 41 Tax Havens \& 21 countries with potentially harmful preferential tax regimes \\
\hline FSF-IMF 2000 & 46 Offshore Financial Centres \\
\hline TJN 2005 & 69 Tax Havens \\
\hline
\end{tabular}

SOURCES:

EU Council, Representatives of the Governments of the Member States 1998 Resolution of the Council and the Representatives of the Governments of the Member States, meeting within the Council of 1 December 1997 on a code of conduct for business taxation. Official Journal of the European Communities, C 002 , 06/01/1998 p.1-6

FSF 2000 Report of the Working Group on Offshore Financial Centres. Basel: Financial Stability Forum.

OECD 1998. Harmful Tax Competition. An Emerging Global Issue. Paris: Organization for Economic Cooperation and Development.

OECD-CFA 2000. Towards Global Tax Cooperation. Paris: OECD.

OECD 2001. The OECD's Project on Harmful Tax Practices: The 2001 Progress Report. Paris: Organization for Economic Cooperation and Development.

OECD 2004. The OECD's Project on Harmful Tax Practices: The 2004 Progress Report. Paris: Organization for Economic Cooperation and Development.

OECD-CTPA(2006). The OECD's Project on Harmful Tax Practices: 2006 Update on Progress in Member Countries. Paris: Organization for Economic Cooperation and Development.

Primarolo Report 1999. Report of the Code of Conduct Group (Business Taxation) to ECOFIN Council, 29 November 1999.

Sharman, Jason 2006. Havens in a Storm. The Struggle for Global Tax Regulation. Ithaca, Cornell U.P.

Van Dijk, Michiel, Francis Weyzig and Richard Murphy 2006 The Netherlands - A tax haven? Amsterdam, Centre for Research on Multinational Organisations (SOMO)

Zoromé, Ahmed. 2007. Concept of Offshore Financial Centers: In Search of an Operational Definition. Working Paper 07/87. Washington DC: IMF.

Acknowledgements:

This Briefing is based on a draft prepared by Laurens Booijink and Francis Weyzig of the Centre for Research on Multinational Corporations (SOMO). 